\title{
EVOLUTION OF KREMLINS AS EVOLUTION OF RUSSIAN URBAN SETTLEMENTS
}

\author{
Ivan Sheremetov ${ }^{1}$, Igor Lagunin ${ }^{2}$ \\ ${ }^{1}$ Astrakhan branch of UNESCO chair the task of which is to preserve architectural \\ and town-planning monuments for future generation, \\ 414000, 2 Trediakovskogo st., Astrakhan, Russia \\ 2Pskov branch of the Russian National Committee of ICOMOS, \\ 180006, 8 «a» Gertcena st., Pskov, Russia \\ 1shrmtv@mail.ru, 2ilagunin@mail.ru
}

\begin{abstract}
The Kremlin is considered to be the first stage of evolution of the urban settlement in the period of strengthening of the Russian centralized state. Five main functions of the kremlin were identified. By now, some functions of Kremlins have been transformed or replaced as a result of turning them into museums.

At the kremlin, the focus is harmoniously shifting from one function to another. The kremlin ensemble evolves with the urban settlement. Formation and development of Kremlins is a phenomenon of the world heritage, a starting point of unique Russian city formation. In order to introduce the concept of the "Russian Kremlin" as a phenomenon to the world community, its basic attributes and key definitions were determined. The current role of preserved kremlin complexes in municipal structures was estimated.
\end{abstract}

\section{Keywords}

Russian Kremlin, outstanding universal value, world heritage, evolution of the urban settlement

\section{Introduction}

In Russian cities, the kremlin has traditionally been the heart of all significant events in a settlement. A fortified center was a birthplace of the majority of Russian cities. Russian cities began their development from such fortified centers. Since any historical period requires proper city-planning decisions, the kremlin appeared as an independent fortified center in a Russian settlement and then developed as the main and the most fortified part of the city. It should be noted that many different people in different countries built fortresses to protect their lands from enemies, while the Russian Kremlin possessed purely defensive functions only at its initial development stages. From the very beginning of the Migration Period and due to some historical reasons, the East Slavs originally began to settle in territories starting with construction of fortified centers, which then became spiritual, craft, trade and economic, administrative and political centers of developing urban settlements and centers of residential areas, and only later on they appeared to be the main cores of cities in the modern sense of the term. The most important Kremlins became command and control centers of Russian ancient lands and principalities. As early as at the time of the Norman invasion of Europe, our land got the name "Gardarike", which means a country of cities (fortresses) (Makovetsky, 2012a).

Each settlement was fenced around to defend it against robberies, invasions, and civil strives typical for the Middle Ages. A protected kremlin (a citadel, or a stronghold), the walls of which were the last obstacle to the enemy and the last protection for citizens, remained the basis of a developed settlement. Most cities had only one inner fortification in their structure, but further development made such a core only a part - although the main one - of a more advanced system of fortifications. It was natural for cities to protect its markets and residential suburbs with earthworks, palisades, and other defense lines. Some large cities eventually erected several rings of stone walls. As a rule, newly fortified parts of cities got their own names. For example, besides the Kremlin and big Zemlyanoy Gorod (earthworks town), Moscow included stone Kitay-gorod and Bely Gorod (White town); in different periods of history, 
Pskov fortress comprised several stone fortification lines: the Kremlin (Stronghold), the Dovmont Wall, the Wall of Posadnik Boris, the Middle Town, the Big Outer Town including fortified Zapskovye. In the first half of the XVII century, Astrakhan as a fortress consisted of the Kremlin, Bely Gorod (White town) and a small fortlet - a Granary. But in all cases a kremlin, a citadel, a stronghold remained a special area of a city endowed with a lot of responsibilities and specific functions, of which the defense function was gradually disappearing and put on a back burner. Pskov as a veche (people's assembly) city was particularly indicative, where the Kremlin (a stronghold) remained, above all, the spiritual and political, representative and administrative center of the republic city, and only then the military and defensive center (rather than a strategic place of storage of grain and weapons, and the last citadel). Residential, trade and craft functions gradually left the Stronghold for the peripheral areas of the city. After the loss of veche independence, memorial and spiritual functions of the Pskov Kremlin, remaining the historical, memorial and spiritual center ("House of the Holy Trinity") for the people of Pskov (Figure 1), became ever increasing.

\section{Subject, objectives and methods}

Starting at least from 1331, the kremlin has been mentioned in Russian chronicles under the term 'Kremnik' (citadel). Its etymology is examined within a semantic analysis of separate complexes (Khait,
2003). The central fortified part of the Russian medieval settlement had several older titles, such as "detinets" (citadel), "krom" (stronghold), "grad" (city) and some others. According to one of versions,

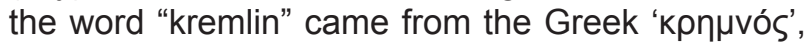
which means "steepy". In the Middle Ages, hundreds of Kremlins were built in Russia. Unfortunately, only about 30 of them survived to the present day. Geographical layout of the most prominent representatives of surviving Kremlins is shown in Figure 2.

As it was noted at the $36^{\text {th }}$ session of the World Heritage Committee of the UNESCO, they, without exaggeration, form "a constellation of Russian Kremlins" on the map.

The Russian Kremlin is a unique phenomenon in the city-planning architectural heritage; it is closely associated with formation and development of cities and all significant events in Russian history. This sententia is also recognized by the international community. As part of compliance with the Convention concerning the Protection of the World Cultural and Natural Heritage and the Operational Guidelines for the Implementation of the World Heritage Convention, the Moscow Kremlin, Novgorod Kremlin, Kazan Kremlin, and Suzdal Kremlin have already been put on the World Heritage List. They are marked with the biggest "stars" in Fig. 1. Such a mechanism of special status awarding to outstanding historical and cultural monuments is recognized as the most effective in

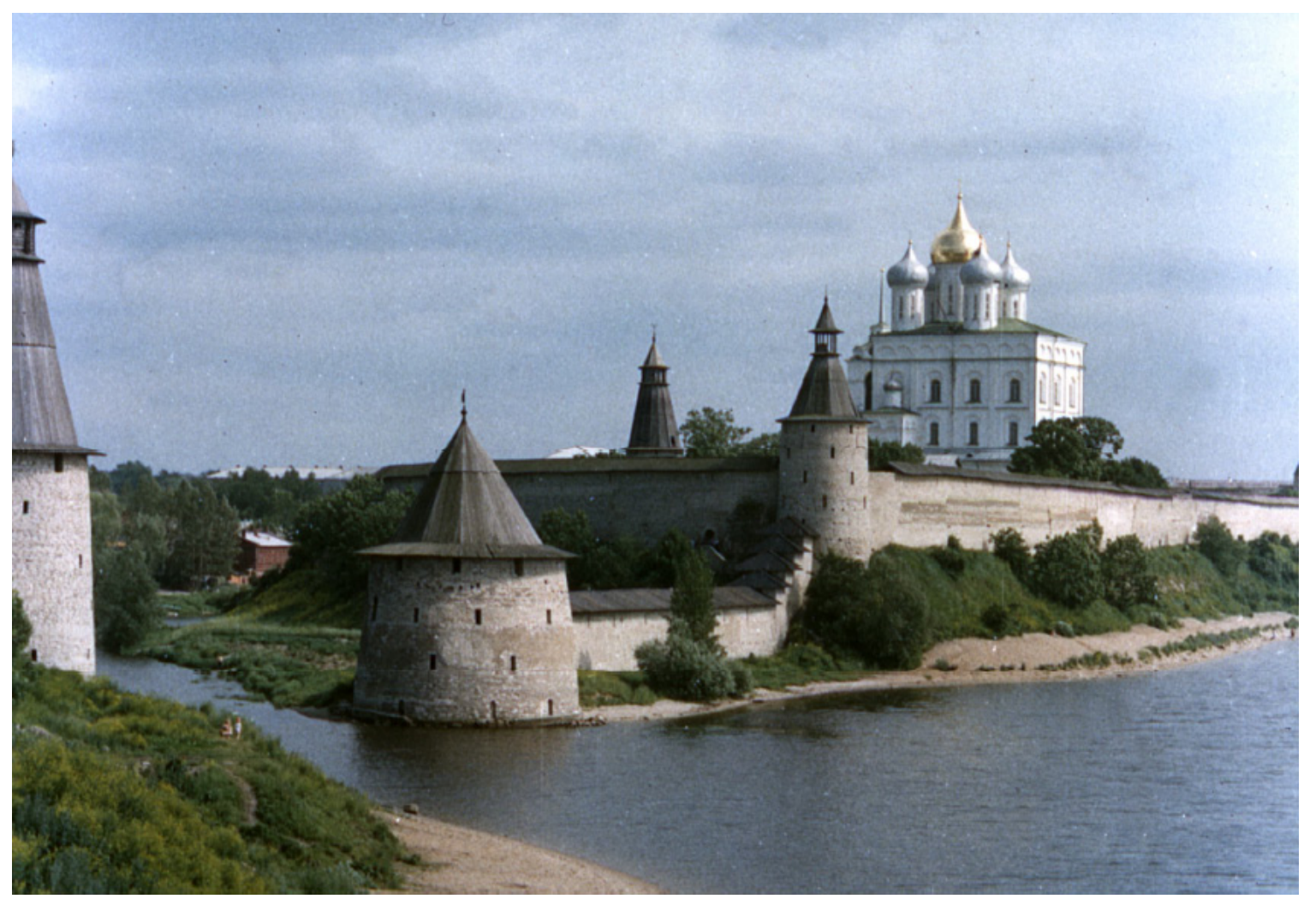

Figure. 1. Pskov Kremlin. General view of the Kremlin ensemble from the north side 


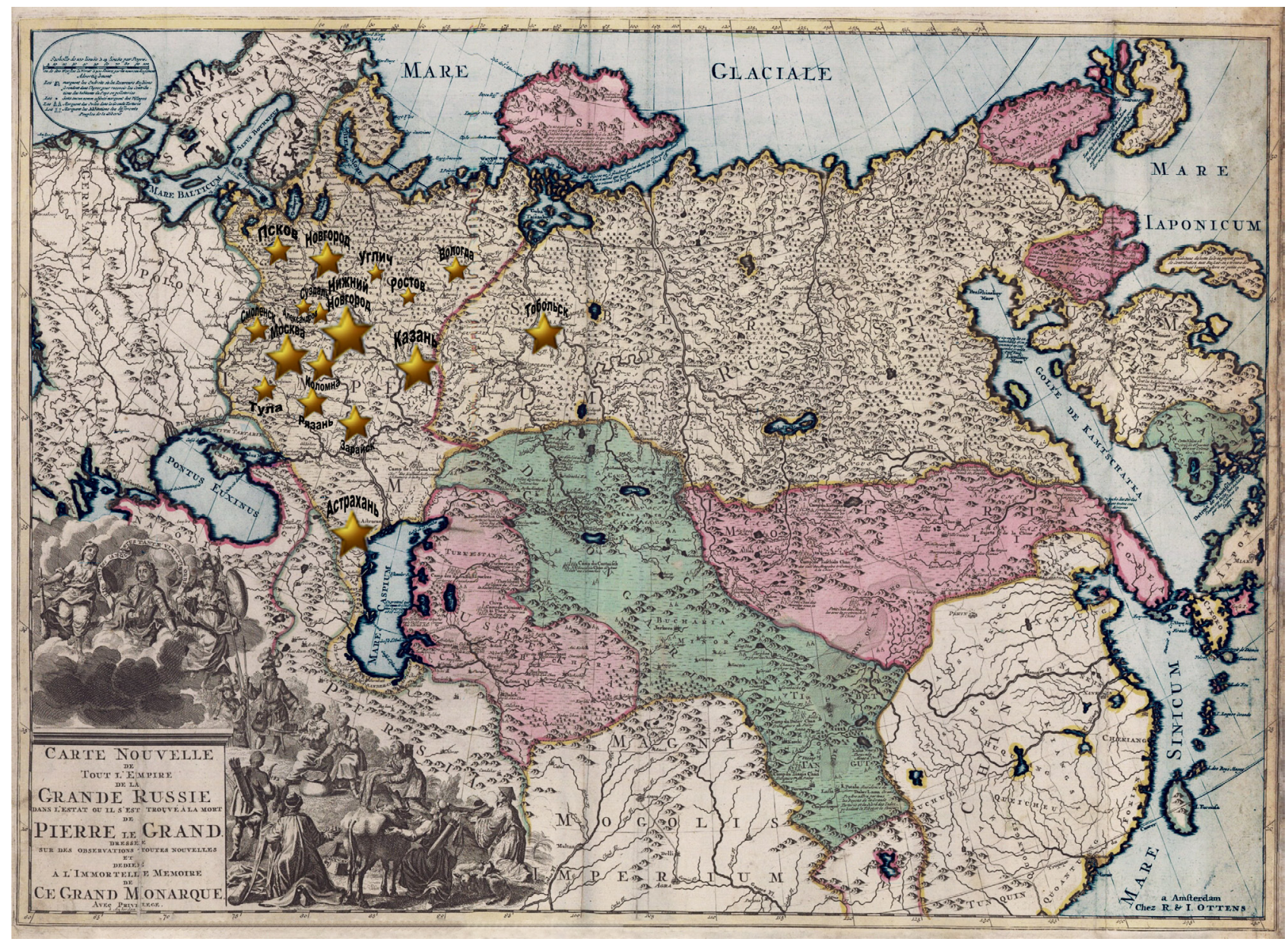

Figure. 2. Location of kremlins on the historical map

the international practice. It should be noted that three of these Kremlins were nominated being a part of complexes of historic development, and only the Kazan Kremlin was nominated as an independent architectural ensemble. In 2010, the preliminary list of World Heritage Sites included special serial nomination "Russian Kremlins", which at the present moment includes the most significant Russian monuments, i.e. the Astrakhan Kremlin, Pskov Kremlin, and Uglich Kremlin. Subsequently, as far as the monuments are ready and prepared and in accordance with the requirements of the ICOMOS and World Heritage Committee, the list is expected to be expanded and it is proposed to add to the serial nomination such significant and well-preserved monuments as the Nizhny Novgorod Kremlin, Tula Kremlin, Tobolsk Kremlin, and Zaraysk Kremlin following basic attributes and key definitions of the nomination. Previously nominated Kremlins are theoretically considered as phenomena, but there is no need to include them into the serial nomination, as they are already world heritage sites. Since all considered Kremlins possess outstanding individual features in addition to the common definition, then extension of the nomination would allow highlighting of the unique phenomenon of the world heritage.
Along with Russian Kremlins, some ensembles similar to them in architectural style, fortification principles, and space planning solutions have been preserved. These include urban fortresses, fortified monasteries, castles or fortified governmental (Alexandrovskaya village) and spiritual residencies (Rostov Kremlin). However, the most significant and characteristic features of this phenomenon are not in its external characteristics, but in functions inherent to kremlins. The main purposes of the fortress are accommodation of a military post, maintaining of its combat capability and strengthening of its defensive potential. The main purposes of the monastery complex are spiritual perfection, solitude for prayers, and refuge from the worldly life for inhabitants of the monastery. The main functions of the castle are residence of the governor, governor's personal troops, administrative specialists and servants, and mandatory isolation from the surrounding dependent population. To different extents, these complexes reveal the above-mentioned elements of functions of Russian Kremlins, but, in contrast to kremlins, only one main function prevails in each of them. The Russian kremlin possesses multifunctionality and specific function that is not inherent to the fortified centers of the East or West. Originally, the Russian 
kremlin existed as a citadel for people of both the city and surrounding counties and administrative territories; it was a spiritual center and focus of power and its political attributes. We also cannot underestimate the role of the kremlin as a depot of strategic military and food supplies, the main memorabilia, art and spiritual things, documentary archives and commercial standards (the Armory Chamber, a treasury of the Moscow Kremlin, is a perfect example). The entire population of the city and vicinity hid and held the fort behind the walls of the Kremlin using it as the last public (!) hiding place in the event of external threats. This fact also distinguishes Kremlins from other similar complexes.

\section{Results and discussion}

In accordance with the postulates set forth, the main features characterizing Russian kremlins were outlined during preparation of the nomination "Russian Kremlins" and their inclusion in the World Heritage List (Makovetsky, 2012b). Three main functions of Russian kremlins named above were expanded with other functions that accompany the fundamental principle of the city. A full list of these features is presented in Table 1.

For centuries, Russian Kremlins performed their main functions. As a result, the kremlin was not only the city fortress, but also a specific central area of the city where governing bodies, churches with religious shrines, strategic reserves, as well as dwellings for the most important citizens and military posts were situated. The main feature of republic cities Novgorod and Pskov is that the military post and dwellings of civil administrators were not allowed to be located in citadels and strongholds. Thus, the kremlin functions depended on the features of the political regime.

The Kremlin was a city itself at the first stage of its evolution. Then, suburbs were constructed around it, as a rule. A trading and economic center of the settlement developed then near the walls of the kremlin. Suburbs developed along the road leading to the kremlin gate towers, meanwhile roads turned into the street network of the city development (Sevan, Ilvitskaya, 2005). Kremlins retained the function of the main city planning focus throughout the life of the city. And even nowadays, the kremlin in Russia is an ancient citadel, which historically outlined the main core and determined the structure of many Russian cities. Location of some kremlin ensembles in the territory of current municipalities is shown in Figure 3.

Some urban arrangements reveal a clear city planning role of the kremlin, while in other cases integration of the historic ensemble into the modern urban development is not always precise but balanced. The city and the Kremlin have always been inseparable and closely related. They have always been an integral unit. We can say that it was the Kremlin that defined the development structure of a future city. The most typical scheme of such development started with a cusp (sectorial) fortified settlement (a future kremlin). Then the development continued with sectorial suburb construction. Then it turned into a segmented development scheme, aiming for a circle arrangement. Evolution of such typical Russian city can be seen through the example of Veliky Novgorod, while the most complete version of such city is Moscow (its historic heart within the Garden Ring Road).

Kremlins have been continuously improved, even in the early days of their development. Since the $11^{\text {th }}$ century, they were rebuilt in stone or brick, surrounded by gaps or moats, completed with fortification earthworks. As a rule, a Prince's Palace, cathedrals, mansions of boyars and clergy of higher ranks, armories and granaries were built in the

Table 1

The main functional features of Russian kremlins

\begin{tabular}{|c|l|l|}
\hline No. & \multicolumn{1}{|c|}{ Function } & \multicolumn{1}{c|}{ Expanded definition } \\
\hline 1 & $\begin{array}{l}\text { Administrative } \\
\text { (Political) }\end{array}$ & $\begin{array}{l}\text { All forms of administrative management concentrated in the kremlin. Here, a voivode, } \\
\text { a Governor's representative, a writ hut consisting of religious and minor officials responsible } \\
\text { for business correspondence and keeping of city archives were located; a court and a prison } \\
\text { were also situated here. }\end{array}$ \\
\hline 2 & Defensive & $\begin{array}{l}\text { The kremlin had a key role as the city citadel. If the enemy moved beyond the outer fortification } \\
\text { of the city, the entire population of the city and soldiers hid in the kremlin, where they held the } \\
\text { fort. For this purpose, there were warehouses for weapons and supplies, barns for food and } \\
\text { wells of fresh water in the territory of the Kremlin. }\end{array}$ \\
\hline 3 & Religious & $\begin{array}{l}\text { It was the religious center. Cathedrals of great beauty were built in the kremlin. Besides the } \\
\text { main cathedral, several churches were built in many kremlins. It was very important for the } \\
\text { spread of Orthodoxy in Russia. As for large kremlins, for example, Moscow, Astrakhan, Kazan } \\
\text { and Kolomna kremlins, even monasteries were located in their territory. }\end{array}$ \\
\hline 4 & $\begin{array}{l}\text { Residential } \\
\text { (settlement } \\
\text { of people) }\end{array}$ & $\begin{array}{l}\text { The kremlin had quite a lot of residential houses, especially in big cities, Moscow, Astrakhan, } \\
\text { Kazan and Nizhny Novgorod Kremlins were severely overcrowded, especially in the } \\
18^{\text {th }} \text { century. Houses of the most privileged citizens were located in the territory of the kremlin. }\end{array}$ \\
\hline 5 & Commercial & $\begin{array}{l}\text { Trading was insignificant inside the kremlin. Meanwhile, the city main market was located right } \\
\text { next to it, outside of the walls of the kremlin. It took great areas, for example, the Red Square } \\
\text { in Moscow. }\end{array}$ \\
\hline
\end{tabular}


a)
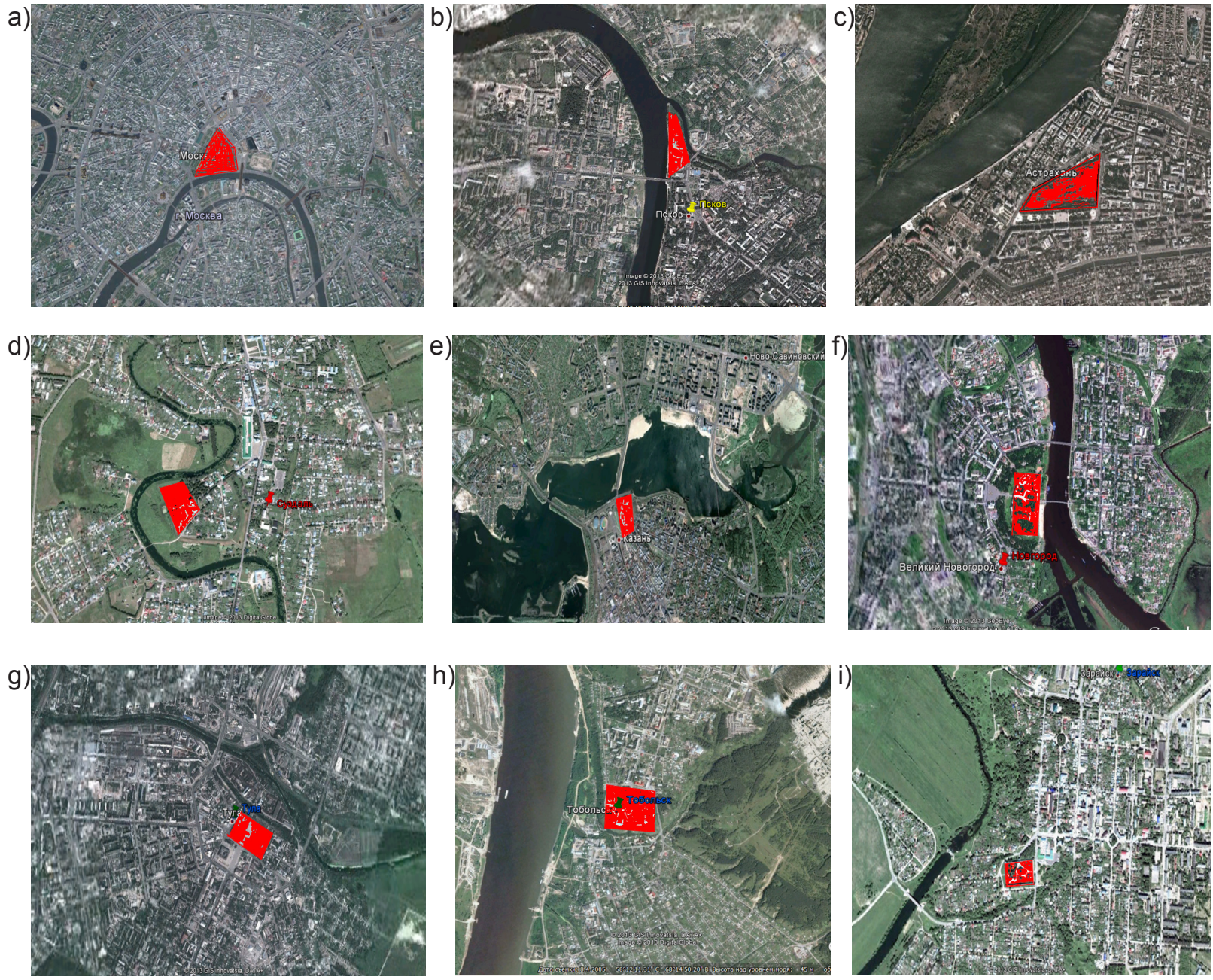

Figure 3. Location of kremlin ensembles in modern urban development: a) Moscow; b) Pskov; c) Astrakhan; d) Suzdal; e) Kazan; f) Veliky Novgorod; g) Tula; h) Tobolsk; i) Zaraysk

Kremlin. The remaining Kremlins were developed or rebuilt in the $16^{\text {th }}-17^{\text {th }}$ centuries, mainly at locations of former earth-and-timber fortifications.

The most outstanding example of such development is the Moscow Kremlin. The place where the Kremlin was built had been known as the "City of Moscow" until the $14^{\text {th }}$ century. The City was significantly expanded by Prince Yuri Dolgorukiy in 1156. In 1366-1368, Dmitry Donskoy replaced the oak works of the fortress with walls of white limestone. Along with strengthening of the Moscow Kremlin fortifications, in 1500-1511, the walls and towers of Pskov and Veliky Novgorod were also rebuilt and fortified. Final establishment of the single Old Russian state and external threats demanded a unified system of external defense that concentrated in Russian Kremlins. South-eastern approaches to Moscow were protected by powerful strongholds; one after another, stone Kremlins were built in Tula (1514-1521), Kolomna (1525-1531), Mozhaysk (1541), Kazan (1555), Serpukhov (1556). At the end of the $16^{\text {th }}$ century, fortress cities, as outposts of the Russian state, were established on the Volga:
Samara (1586), Saratov (1590), Tsaritsyn (currently Volgograd) (1589), Astrakhan (1558). Fortified settlements were developed in Siberia: Tyumen (1596), Tobolsk (1587), Tara (1594), Surgut (1504) and others. The final step was construction of the western Smolensk frontier (1597-1602).

Thus, during a short period of time, in the $16^{\text {th }}$ century, a unified national system of kremlin complexes was established in Russia. It covered almost all lands, united into the Russian State by that time. The main feature of that time was construction of fortress Kremlins, which originally protected the entire perimeter of existed settlements (Smolensk, Nizhny Novgorod, Astrakhan). Russian Kremlins became the basis of the defense system, remaining active centers of city formation. This was one of the main factors, which combined all Kremlins into a single unit at that period. Formation and development of each kremlin is the most important component of historical formation of the Russian state.

Considering the above, it becomes clear that the concept of the "Russian Kremlin" has a multiplemeaning nature and has developed over centuries, 
changing its basic features and definitions. It should be noted that this multiple meaning sometimes allows researchers attributing other fortified centers and settlements to Russian Kremlins.

In order to show the world community the concept of the "Russian Kremlin" as a phenomenon, we established its basic characteristics and key definitions (Sheremetov, Lagunin, 2013). Nine key definitions and attributes of the concept "Russian Kremlin" were proposed, which correspond to notions of originality of this phenomenon and justify its outstanding universal value to the fullest extent possible. They are presented in Table 2. Kremlin ensembles that most clearly and vividly reflect certain basic attributes are also stated here, since only within the framework of a serial nomination outstanding features and different stages of development can be communicated to the fullest extent possible, confirming key definitions and disclosing key attributes of such amazing heritage site as the "Russian Kremlin", common for Russia.

Remaining a cradle of the city, the kremlin was certainly positioned in different ways in different historical periods. Development not always resulted in strengthening of the attributes peculiar to the kremlin. If some of the defining features decayed, a complex ceased to correspond to the key attributes of the concept "Russian Kremlin". For example, the Alexandrovsky Kremlin was transformed into a royal residence, while some other Kremlins were turned into residences for religious institutions.
In accordance with the definitions of the basic attributes established by the authors for Russian Kremlins that had the most distinctive development in the Russian State history and outstanding universal value for the world culture, as well as in accordance with the basic features inherent to these objects, the concept of "Russian Kremlin" is a fully characteristic of preserved complexes represented in Table 3 . Here, the sign "!" marks the most vividly manifested attributes in stated Kremlin complexes. Not all other ensembles can be characterized by key definitions to the full. In some cases, these attributes had been lost over time, while others had not been developed. However, all preserved kremlin complexes without exception remain the "heart" of the city. Kremlin ensembles preserved in cities remain a focus of city planning in most of them and continue to play their role in the life of the settlement. Kremlins often form a structure of a social center being a site for various public events and a main sightseeing place in cultural tourism programs.

As it has been already mentioned, up to the present time, some functions of Kremlins have been transformed, and others have been substituted as a result of modern adaptation and turning them into museums. Data on transformations, as a rule, correlate to changes in the city development. Largescale cultural events are held in Kremlins; various creative authors find here a site for implementation of their ideas. It can be clearly seen through the example of the Astrakhan Kremlin. Citizens have

Table 2

Key attributes and definitions of the concept "Russian Kremlin"

\begin{tabular}{|c|c|c|}
\hline No. & Key definitions (attributes) & $\begin{array}{l}\text { Most outstanding } \\
\text { representatives }\end{array}$ \\
\hline 1 & $\begin{array}{l}\text { A center of origin of outstanding historical cities of ancient Russia, keeping the memory } \\
\text { of a long history of an urban settlement starting from initial stages of its development; } \\
\text { a monument of archeology and history, storing nonmaterial evidences and values. }\end{array}$ & $\begin{array}{l}\text { Kremlins in Moscow, } \\
\text { Pskov and Uglich }\end{array}$ \\
\hline 2 & $\begin{array}{l}\text { An original and unique in its structure central ensemble of an ancient Russian city; } \\
\text { a prominent political, administrative and representative center of a historic city, preserving } \\
\text { traces of different historical eras in its architecture and planning decisions. }\end{array}$ & $\begin{array}{l}\text { Kremlins in Moscow, } \\
\text { Pskov, Novgorod }\end{array}$ \\
\hline 3 & $\begin{array}{l}\text { Guardians of traces and monuments of international and interethnic cultural contacts in the } \\
\text { Russian history. }\end{array}$ & $\begin{array}{l}\text { Kremlins in Kazan } \\
\text { and Astrakhan }\end{array}$ \\
\hline 4 & $\begin{array}{l}\text { A unique monument and achievement of original Russian and international art of fortification; } \\
\text { a monument to the history of heroic defense of the Russian state. }\end{array}$ & $\begin{array}{l}\text { Kremlins in Tula, } \\
\text { Nizhny Novgorod } \\
\text { and Astrakhan }\end{array}$ \\
\hline 5 & $\begin{array}{l}\text { An outstanding and holistic ensemble of stone architecture, preserving rare examples of } \\
\text { national architecture, included into the anthology of the Russian architecture, and examples } \\
\text { of mural, arts and crafts, and examples of original craftsmanship, use of traditional } \\
\text { techniques and materials of local art schools. }\end{array}$ & $\begin{array}{l}\text { Kremlins in Moscow, } \\
\text { Astrakhan, Pskov } \\
\text { and Uglich }\end{array}$ \\
\hline 6 & $\begin{array}{l}\text { Outstanding focus of city planning and the center of city planning structure merged with the } \\
\text { natural landscape of a historical Russian city. }\end{array}$ & $\begin{array}{l}\text { Kremlins in Tobolsk } \\
\text { and Pskov }\end{array}$ \\
\hline 7 & $\begin{array}{l}\text { A historical ensemble of rare beauty and preservation in the landscape of an ancient Russian } \\
\text { city and urban ensemble; an example of blending with the natural environment, landscape } \\
\text { and historical buildings. }\end{array}$ & $\begin{array}{l}\text { Kremlins in Moscow, } \\
\text { Zaraysk and } \\
\text { Astrakhan }\end{array}$ \\
\hline 8 & A unique example of a memorial and sacred ensemble in the Russian city. & Uglich Kremlin \\
\hline 9 & $\begin{array}{l}\text { A spiritual Orthodox and sacred center of the Russian city, where outstanding temples, } \\
\text { cathedrals, necropoles, and monuments of church architecture and archeology play } \\
\text { a crucial role in an ensemble. }\end{array}$ & $\begin{array}{l}\text { Kremlins in Suzdal } \\
\text { and Novgorod }\end{array}$ \\
\hline
\end{tabular}


Table 3

Characteristics of kremlins complying with key attributes and definitions

\begin{tabular}{|c|c|c|c|}
\hline No. & Name & $\begin{array}{c}\text { Items of key } \\
\text { attributes }\end{array}$ & Characteristics of the object \\
\hline 1 & $\begin{array}{l}\text { Moscow } \\
\text { Kremlin }\end{array}$ & $\begin{array}{l}1(!), 2(!), 3 \\
4,5(!), 6,7 \\
8,9\end{array}$ & $\begin{array}{l}\text { An outstanding and the most architecturally developed example of a metropolitan } \\
\text { kremlin ensemble; it preserved not only the traces of centuries-old history but prominent } \\
\text { ensembles of fortress, civil and church architecture, retaining the function of the main } \\
\text { political center and symbol of the country. }\end{array}$ \\
\hline 2 & $\begin{array}{l}\text { Novgorod } \\
\text { Kremlin }\end{array}$ & $\begin{array}{l}1,2,3,4,5 \\
6,7,8,9(!)\end{array}$ & $\begin{array}{l}\text { An outstanding ancient ensemble of a metropolitan kremlin of the Novgorod Republic; } \\
\text { it was rebuilt in brick after the republic was joined to the unified centralized state. } \\
\text { It preserved in its ensemble prominent monuments of architecture and art such as the } \\
\text { cathedral church of St. Sophia (mid XI century) and the monument "Millennium of Russia" } \\
\text { as a symbol of one of the first capitals of the ancient Russia (1862). }\end{array}$ \\
\hline 3 & $\begin{array}{l}\text { Suzdal } \\
\text { Kremlin }\end{array}$ & $\begin{array}{l}1,2,3,4,5 \\
6,7,8,9(!)\end{array}$ & $\begin{array}{l}\text { Kremlin of the capital of one of the most ancient Russian principalities; it preserved such } \\
\text { monuments as the Cathedral of Nativity of the Theotokos built in the XII century and } \\
\text { Archbishop's Chambers of the XV-XVII centuries. }\end{array}$ \\
\hline 4 & $\begin{array}{l}\text { Kazan } \\
\text { Kremlin }\end{array}$ & \begin{tabular}{|l}
$1,2,3(!), 4$ \\
$5,6,7,8,9$
\end{tabular} & $\begin{array}{l}\text { An outstanding frontier fortress kremlin built in the middle of the XVI century in the } \\
\text { former capital of the Kazan Khanate; it possesses the cathedral complex, traces and } \\
\text { monuments of the history of two national cultures. }\end{array}$ \\
\hline 5 & $\begin{array}{l}\text { Pskov } \\
\text { Kremlin }\end{array}$ & $\begin{array}{l}1,2,3,4 \\
5(!), 6(!), 7 \\
8,9\end{array}$ & $\begin{array}{l}\text { A complex of the VIII-XIX centuries; it preserved archaeological monuments and traces } \\
\text { of a } 1100 \text { year-old history of the city, unique structures of the capital veche center typical } \\
\text { for Russian cities, including a temple ensemble of the Dovmont city (archaeological } \\
\text { monument in the open air). A prominent beautiful architectural ensemble in the landscape } \\
\text { of the historical city blending with the natural environment. }\end{array}$ \\
\hline 6 & \begin{tabular}{|l|} 
Uglich \\
Kremlin
\end{tabular} & $\begin{array}{l}1,2,3,4 \\
5(!), 6,7 \\
8(!), 9\end{array}$ & $\begin{array}{l}\text { A complex of the X-XVII centuries. An example of an earth-and-timber fortification } \\
\text { that survived several construction phases and preserved an ensemble of sacred and } \\
\text { memorial stone buildings, including the oldest in Russia preserved Appanaged Princes' } \\
\text { Palace", the Church of Tsarevich Dmitry on the Blood (XVI century), built on banks of the } \\
\text { Volga where the last legitimate heir to the throne, the son of Ivan the Terrible was killed } \\
\text { (1592). Here, remarkable ensembles of wall paintings, including those dedicated to local } \\
\text { events, retained. }\end{array}$ \\
\hline 7 & $\begin{array}{l}\text { Astrakhan } \\
\text { Kremlin }\end{array}$ & $\begin{array}{l}1,2,3(!), 4 \\
5,6,7(!) \\
8,9\end{array}$ & $\begin{array}{l}\text { A complex of the XVI-XVII centuries - beginning of the XX century. A fortress kremlin } \\
\text { of the final period of development of Russian fortress architecture with outstanding } \\
\text { fortress facilities remained in the full ensemble, including military constructions of } \\
\text { the XIX century. Cathedrals of the Kremlin ensemble include a prominent example of } \\
\text { Russian baroque - the Cathedral of the Assumption with a unique adjoining elevated } \\
\text { circular platform of the Lobnoye Mesto (the Place of Execution). }\end{array}$ \\
\hline 8 & $\begin{array}{l}\text { Nizhny } \\
\text { Novgorod } \\
\text { Kremlin } \\
\end{array}$ & \begin{tabular}{|l|}
$1,2,3,4(!)$ \\
$5,6,7,8,9$
\end{tabular} & $\begin{array}{l}\text { A kremlin of the XIV-XVI centuries. A well-preserved multi-towered ensemble of one } \\
\text { of the major fortress kremlins on the Volga; it had lost its strategic significance after } \\
\text { the conquest of Kazan. Stone construction started in the end of the XIV century. }\end{array}$ \\
\hline 9 & $\begin{array}{l}\text { Zaraysk } \\
\text { Kremlin }\end{array}$ & $\begin{array}{l}1,2,3,4,5 \\
6,7(!), 8,9\end{array}$ & $\begin{array}{l}\text { A complex of the first quarter of the XVI century. One of the most well-preserved stone } \\
\text { kremlins with seven towers and three gates. It preserved cathedrals dating to the end of } \\
\text { the XVII century and the beginning of the XX century, an administrative building and the } \\
\text { building of a religious school of the XIX century. }\end{array}$ \\
\hline 10 & $\begin{array}{l}\text { Tula } \\
\text { Kremlin }\end{array}$ & $\begin{array}{l}1,2,3,4(!) \\
5,6,7,8,9\end{array}$ & $\begin{array}{l}\text { XVII century. It has a unique location, being hidden in a valley of the countryside; the } \\
\text { stone Tula Kremlin was the main fortified center of the Zasechnaya cherta (Great Abatis } \\
\text { Border) and the most combative southern fortress of the Russian state. }\end{array}$ \\
\hline 11 & $\begin{array}{l}\text { Tobolsk } \\
\text { Kremlin }\end{array}$ & $\begin{array}{l}1,2,3,4,5 \\
6(!), 7,8,9\end{array}$ & $\begin{array}{l}\text { An ensemble dating back to the end of the XVII century. A well-preserved ensemble } \\
\text { of one of the latest built kremlins and the most easterly situated stone kremlin in Russia; } \\
\text { it was built after the conquest of the Siberian Khanate. It has a wonderful location } \\
\text { in the natural and historical landscape of the city. }\end{array}$ \\
\hline
\end{tabular}

already accustomed to Days of Russian Literature, New Year and Maslenitsa festivities traditionally held in the territory of the Kremlin, and in September 2012 they were going to the first-night. As a result of five-year rehearsals at the cathedral square, the Astrakhan State Theatre of Opera and Ballet presented a new production - the opera "Boris Godunov" by Modest Mussorgsky. The choice was not at all accidental. Prior to ascending to the throne, Boris Godunov was the governor of the Astrakhan Kingdom. This spectacular cultural event once again reminded of the historical fact that the Astrakhan Kremlin acquired its stone appearance which remained till our days during ruling of this governor. The Astrakhan Kremlin became the most perfect defensive building of the Moscow State. The area of the Kremlin allowed hiding all citizens behind its strong walls in the event of an enemy attack. Performing the function of the city, where population dwelled, the Kremlin had great social significance and was closely interconnected with surrounding settlements. Here, all administrative structures 
concentrated, and a local representative of the ruler, a voivode, had a residence (Sheremetov, Levitan, 2013).

Taking into account current development of communication technologies, we can estimate attitudes of the population to such an important from the historical point of view - object as the kremlin ensemble by studying responses of the Web community. The project "Russia 10" which launched online in March 2013 demonstrated interest of citizens to kremlin complexes (http://10russia.ru). The ensemble of the Pskov Kremlin confidently entered the Top Ten during the nationwide votes; earlier the Kremlin had acquired the brand of the ancient Hanseatic Pskov. All this is fully consistent with principles of the UNESCO reflected in Chapter I.C of the Guidelines for the Implementation of the World Heritage Convention. According to Clause $15 \mathrm{~m}$, the Parties to the Convention commit themselves to "use educational and information programs to strengthen appreciation and respect by their peoples of the cultural and natural heritage".

A complex mechanism of interaction of the historical and cultural complex with a modern municipality assumes some feedback. Not only the Kremlin meets the needs of the city, but also the society takes care of the Kremlin. Authorities of constituent regions and municipalities, as a rule, tend to coordinate their programs aimed at preserving monuments with government agencies and "giving the heritage a function in the life of the community", according to Clause 15b of Chapter I.C of the Guidelines for the Implementation of the World Heritage Convention. The Ministry of Culture of the Russian Federation (http://mkrf.ru/)developed the Plan of administrative and financial activities within the framework of the federal target program "Culture of Russia (2012-2018)" which was approved by Order No. 88 of the Ministry of Culture of the Russian Federation (http://mkrf.ru/) as of February $5^{\text {th }}, 2013$. The program covers designing and restoration of kremlin complexes in Pskov, Porkhov, Tula, Astrakhan, Ryazan, Veliky Novgorod and other similar objects (http://mkrf.ru).

\section{Conclusions}

Thus, the Kremlin is a cornerstone of evolution of Russian urban settlements. Being a fundamental principle, it defined the planning structure of a future Russian city. The Kremlin defined the administrative status of a settlement. The Kremlin promoted development of trading and, therefore, prosperity of settlements, providing security. All important aspects of development and life of the city strengthened under the influence of the kremlin. The kremlin became a starting point of evolution of the urban settlement. And till now it remains the historic center of the city. Kremlin complexes with appropriate key attributes and definitions retained their role in the lives of urban population with account for current trends. For example, fortification elements of complexes were turned into museums or transformed into memorial objects attracting not only researchers but also other population groups. Some functions (such as city planning, representative functions, role of spiritual and administrative center) persist up to date in some cases. The Kremlin is enriched by cultural tourism components meeting today's needs. Throughout the history, Kremlins changed together with the city. Developing together with the urban settlement, some of their functions transformed into another ones harmoniously. Formation and development of Kremlins is a phenomenon of the world heritage and a counterpoint to the unique Russian city formation.

\section{Acknowledgements}

The authors are grateful to Alexander Valentinovich Sychev, a regional representative of the ICOMOS in Uglich, for providing of information about the objects of the Uglich Kremlin.

\section{References}

Khait, V. (2003). Semantics of kremlins and the Moscow Kremlin. In: Russian Kremlins: Materials and Researches, Issue XV. Moscow: Moscow Federal State Institution "State Historical and Cultural Museum-Preserve "The Moscow Kremlin", pp. 16-23. (in Russian)

Makovetsky, I. (ed.) (2012a). The Kremlins of Russia. Astrakhan. Pskov. Uglich. Astrakhan: Printing house "Nova" LCC, $156 \mathrm{p}$.

Makovetsky, I. (ed.) (2012b). The Kremlins of Russia. Astrakhan. Astrakhan: Printing-house "Nova" LCC, 120 p. (in Russian)

Sevan, O., Ilvitskaya, S. (2005). Kreml v strukture rossiiskogo goroda: sotciokulturnye funktcii [The kremlin in the structure of a Russian city: social and cultural functions]. Observatory of Culture Journal, 3, pp. 78-83. (in Russian)

Sheremetov, I., Lagunin, I. (2013). Bazisnye atributy i kliuchevye opredeleniia poniatiia "Russkii kreml” [The key attributes and definitions of the concept "Russian Kremlin"]. Scientific potential of regions in the service of modernization, 1 (4), pp. 124-131. (in Russian)

Sheremetov, I., Levitan, I. (2013). Fortifikatcionnyi aspekt evoliutcii Astrakhanskogo kremlia v protcesse ukrepleniia Russkogo tcentralizovannogo gosudarstva [Fortification aspect of evolution of the Astrakhan Kremlin in the process of strengthening of the centralized Russian state]. Scientific potential of regions in the service of modernization, 1 (4), pp. 131-136. (in Russian) 